\title{
Pengaruh bentuk bubu terhadap hasil tangkapan rajungan portunus pelagicus di perairan pantai Desa Kema tiga Kabupaten Minahasa Utara Provinsi Sulawesi Utara
}

\author{
The effect of pots shape toward the catch of swimming crab in coastal waters Kema Tiga \\ Village, North Minahasa Regency of North Sulawesi Province
}

\author{
MOCH. ABDUL CHALIM*, JOHNNY BUDIMAN dan EMIL REPPIE
}

Program Studi Pemanfaatan Sumberdaya Perikanan, Fakultas Perikanan dan Ilmu Kelautan, Universitas Sam Ratulangi, Manado 95115

\begin{abstract}
Swimming crab (Portunus pelagicus) is one of the fishery commodities that have high sales value for which raced flavor and high nutritional content. This swimming crab in coastal waters of North Sulawesi usually caught accidentally (by catch) with bottom gillnets. There has been a special fishing gear for crab traps, but not known by local fishermen. The differences of trap shape could increase the fishing power of swimming crab traps; but such scientific information is not widely available yet. Therefore, this research aimed to study the effect of pots shape to catch swimming crab; and identifies the types of biota captured. This research was conducted in the coastal waters of Kema Tiga village, North Minahasa Regency; from September to December 2014; which is based on the experimental method. Bubu six units of traps (three units conical shape, and three other rectangular shape), operated for eight nights to collect data; used scad mackerel bait; and the capture data were analyzed by t test. The catch was 86 swimming crab in total; 56 was caught by conical shape traps, and 30 individuals were caught by rectangular shape traps. Analysis of test showed that $\mathrm{t} 0=4.596>\mathrm{t}$ table $0.01 ; 7=3.499$, which means that the use of conical shape traps, giving highly significantly different swimming crab catches compared to rectangular shape traps.
\end{abstract}

Keywords: Swimming crab, trap, mackerel bait, North Minahasa

\begin{abstract}
ABSTRAK
Rajungan (Portunus pelagicus) merupakan salah satu komoditi perikanan yang memiliki nilai jual tinggi karena memiliki rasa yang lezat dan kandungan gizi yang tinggi). Rajungan ini di perairan pantai Sulawesi Utara biasanya tertangkap tanpa sengaja (by catch) dengan jaring insang dasar. Sebenarnya telah ada alat tangkap bubu khusus untuk rajungan, tetapi belum dikenal oleh nelayan lokal. Perbedaan bentuk bubu diduga dapat meningkatkan kemampuan tangkap dari bubu ranjungan; namun informasi ilmiah seperti ini belum banyak tersedia. Oleh karena itu, penelitian ini bertujuan untuk mempelajari pengaruh bentuk bubu terhadap hasil tangkapan ranjungan; dan mengidentifikasi jenis-jenis biota yang tertangkap. Penelitian ini dilakukan di perairan pantai Desa Kema Tiga, Kabupaten Minahasa Utara; pada bulan September sampai Desember 2014; yang didasarkan pada metode eksperimental. Enam unit bubu (tiga unit bentuk kerucut terpancung dan tiga unit bentuk empat persegi) dioperasikan selama delapan malam untuk mengumpulkan data; menggunakan umpan ikan layang; dan data dinalisis dengan uji t. Tangkapan total berjumlah 86 ekor; 56 ekor tertangkap dengan bubu bentuk kerucut terpancung, dan 30 ekor tertangkap dengan bubu bentuk empat persegi. Hasil analisis menunjukan bahwa $\mathrm{t}$ hitung $=$ $4,596>\mathrm{t}$ tabel 0,$01 ; 7=3,499$, yang berarti bahwa penggunaan konstruksi bubu bentuk kerucut terpancung, memberikan hasil tangkapan rajungan yang sangat berbeda nyata dibandingkan dengan konstruksi bubu empat persegi.
\end{abstract}

Kata-kata kunci: Rajungan, bubu, umpan ikan layang, Minahasa Utara.

\footnotetext{
*Penulis untuk penyuratan; e-mail: calimkkp@yahoo.co.id
} 


\section{PENDAHULUAN}

\section{Latar Belakang}

Rajungan (Portunus pelagicus) merupakan salah satu komoditi hasil laut ekonomis penting yang dihasilkan dari perairan pantai Indonesia. Permintaan pasar terhadap komoditas ranjungan terus meningkat. Di beberapa Negara seperti Amerika Serikat, Jepang, Korea Selatan, Taiwan dan Australia, komoditas ranjungan tetap menjadi konsumsi penting sehingga merupakan pangsa pasar ekspor yang srategis dengan nilai jual yang tinggi. Komiditas ranjungan dari dalam negeri hasil penangkapan ikan mendominasi produk untuk ekspor (Zarochman, 2006). Selanjutnya Asmara (2004), menyebutkan bahwa rajungan merupakan komoditi perikanan yang memiliki nilai jual tinggi karena memiliki rasa yang lezat dan kandungan gizi yang tinggi.

Bubu (portable trap) merupakan salah satu alat tangkap yang umum digunakan oleh masyarakat nelayan untuk menangkap ikan-ikan dasar, ikan karang dan biota laut lainnya termasuk kepiting rajungan, karena konstruksinya sederhana, relatif murah dan mudah dioperasikan dengan kapal atau perahu ukuran kecil. Sayangnya, praktek pengoperasian bubu tradisional biasanya bersifat merusak, dimana nelayan menutup alat tangkap dengan patahan karang hidup untuk menarik spesies target (Reppie, 2010).

Alat tangkap bubu telah digunakan dengan sangat beragam di seluruh dunia, baik bentuk desain maupun ukuranya, tetapi konsep dasarnya adalah sama pada semua kasus yaitu ikan atau hewan laut lainnya akan masuk ke dalam bubu melalui satu atau lebih pintu yang berbentuk kerucut (Munro, 1974). Berdasarkan pada metode operasi ini, maka bubu diklasifikasikan sebagai alat tangkap pasif; dan ikan atau hewan laut lainnya dirangsang dengan umpan untuk masuk ke dalam bubu.

Keberhasilan alat tangkap bubu sangat bergantung pada tingkah laku hewan laut yang menjadi target penangkapan; kemudian ukuran alat tangkap yang bertindak sebagai fishing function; dimana hewan laut tersebut dapat masuk dan meloloskan diri (Reppie, 1989). Selanjutnya, mekanisme tangkapan bubu menunjukan bahwa, jika sebuah alat tangkap bubu dioperasikan di laut selama waktu tertentu (hari), maka sejumlah tangkapan akan diperoleh di dalam bubu. Hasil tangkapan tersebut mungkin akan berkurang akibat terdapat ikan yang meloloskan diri, dimangsa oleh predator atau adanya kanibalisasi di dalam bubu. Ikan meloloskan diri, dapat terjadi sehubungan dengan kejenuhan alat tangkap (saturation of gear) dan berkurangnya daya tarik umpan.

Rajungan (Portunus pelagicus) di perairan pantai Sulawesi Utara biasanya tertangkap tanpa sengaja (by catch) dengan jaring insang dasar. Sebenarnya telah ada alat tangkap bubu khusus untuk rajungan, tetapi belum dikenal oleh nelayan lokal. Perbedaan bentuk bubu diduga dapat meningkatkan kemampuan tangkap dari bubu ranjungan; namun informasi ilmiah seperti ini belum banyak tersedia.

Reppie (1989), menyatakan bahwa perikanan bubu mempunyai kelebihan dalam pengelolaan jika dibandingkan dengan usaha perikanan lainnya, dimana hasil tangkapan pada umunya diperolah masih dalam keadaan hidup, sehingga disamping dapat terjamin kesegaran yang tinggi, juga mudah dalam pengelolaan sumberdaya perikanan; seperti melepaskan hasil tangkapan kembali ke laut jika ukurannya belum layak ditangkap (legal size).

\section{Tujuan penelitian}

Penelitian ini bertujuan untuk: Mempelajari pengaruh perbedaan konstruksi bubu terhadap hasil tangkapan rajungan dan mengidentifikasi hasil tangkapan bubu.

\section{METODOLOGI PENELITIAN}

Penelitian ini dilakukan di perairan pantai Desa Kema Tiga, Kabupaten Minahasa Utara; pada bulan September sampai Desember 2014; yang didasarkan pada metode eksperimental (Nasir, 1999). Bahan dan alat yang digunakan terdiri dari: 6 unit alat tangkap bubu (tiga unit bentuk kerucut terpancung dan tiga unit bentuk empat persegi), perahu bermotor 1 unit, umpan ikan malalugis (Decapterus macarellus), bahan bakar bensin dan olie, dan alat tulis menulis.

Alat tangkap yang telah berumpan diturunkan sore hari di dasar perairan pada kedalaman sekitar $5-0 \mathrm{~m}$, dibiarkan semalam kemudian diangkat pada besok paginya. Hasil tangkapan dicatat dan diidentifikasi berdasarkan perlakuan dan trip operasi.

Untuk memenuhi persyaratan analisis dalam menarik kesimpulan, maka dirumuskan hipotesis sebagai berikut: 
$\mathrm{H}_{0}=$ Perbedaan konstruksi bubu tidak memberikan hasil tangkapan rajungan yang berbeda nyata;

$\mathrm{H}_{1}=$ Perbedaan konstruksi bubu memberikan hasil tangkapan rajungan yang berbeda nyata;

dimana: $\mathrm{H}_{0}$ diterima apabila $\mathrm{t}$ hitung $\leq \mathrm{t}$ tabel, $\mathrm{H}_{0}$ ditolak apabila $\mathrm{t}_{\text {hitung }} \geq \mathrm{t}$ table.

Selanjutnya $\mathrm{t}$ hitung dikerjakan menggunakan analisis perbandingan nilai tengah contoh pengamatan berpasangan (Steel and Torrie, 1989), dengan rumusan:

$$
\begin{aligned}
& t=\frac{\bar{X}-\bar{Y}}{S_{\bar{D}}} \\
& S_{\bar{D}}=\frac{\sum D^{2}-\left(\sum D\right)^{2} / n}{n-1} \\
& t=\frac{\bar{X}-\bar{Y}}{\sqrt{\frac{\sum D^{2}-\left(\sum D\right)^{2} / n}{n-1}}}
\end{aligned}
$$

\section{Dimana:}

$\bar{X}=$ rata-rata tangkapan bubu konstruksi bentuk kerucut terpancung

$\bar{Y}=$ rata-rata tangkapan bubu konstruksi bentuk empat persegi

$\mathrm{D}=\mathrm{X}-\mathrm{Y}$

Taraf nyata $(\alpha)=5 \%(0,05)$

\section{HASIL DAN PEMBAHASAN}

\section{Hasil Tangkapan}

Hasil tangkapan bubu selama penelitian berjumlah 86 ekor rajungan, sebanyak 56 ekor tertangkap dengan bubu konstruksi kerucut terpancung dan 30 ekor tertangkap dengan bubu konstruksi empat persegi. Sebaran hasil tangkapan rajungan pada setiap trip dan ulangan disajikan dalam Tabel 1.

Hasil analisis menunjukan bahwa t hitung = $4,596>\mathrm{t}$ tabel 0,$01 ; 7=3,499$ pada tingkat kepercayaan 99\%; sehingga menolak $\mathrm{H}_{0}$ dan menerima $\mathrm{H}_{1}$, dimana hal ini ini menjelasan bahwa penggunaan konstruksi bubu bentuk kerucut terpancung (Gbr 1), memberikan hasil tangkapan rajungan yang sangat berbeda nyata dibandingkan dengan konstruksi bubu empat persegi (Gbr 2).

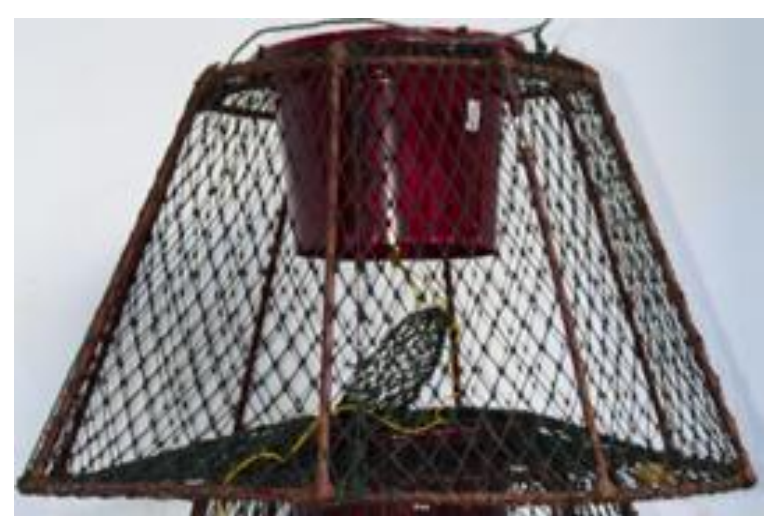

Gambar 1. Bubu bentuk kerucut terpanjung.

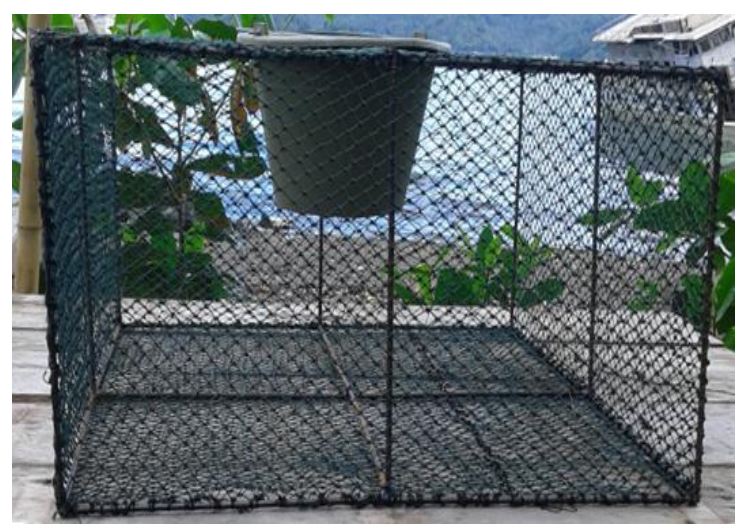

Gambar 2. Bubu bentuk empat persegi.

\section{Pembahasan.}

Konstruksi bubu yang terbuat dari besi dengan posisi pintu masuk yang vertikal (menghadap ke atas) menggunakan ember plastik (silender plastic) yang berdiameter $18 \mathrm{~cm}$, memungkinkan kepiting yang masuk tidak bisa meloloskan diri karena terhalang silender plastik yang licin bagi kepiting untuk merangkak.

Hasil tangkapan bubu konstruksi kerucut terpancung sebanyak 56 ekor (65.12\%), jauh lebih banyak dari hasil tangkapan bubu konstruksi empat persegi yang jumlah hasil tangkapan sebanyak 30 ekor (34.88\%), karena rajungan lebih berhasil memanjat dinding bubu konstruksi bentuk kerucut terpancung yang agak miring daripada memanjat dinding bubu konstruksi bentuk empat persegi yang tegak vertical.

Besarnya diameter pintu masuk juga menentukan besarnya ukuran hasil tangkapan yang diperoleh. Reppie (1989), mengemukakan bahwa alat tangkap menggunakan bubu dipengaruhi oleh banyak faktor, antara lain: konstruksi alat, waktu penangkapan, jenis dan kualitas umpan, kondisi 
oseanografis, kepadatan populasi dan reaksi ikan atau biota laut terhadap alat tangkap. Pergerakan kepiting ketika memasuki konstruksi bubu besi adalah dengan memanjat dinding bubu yang terbuat dari jaring, kemudian masuk melalui mulut yang terletak pada bagian atas. Setelah berada dalam bubu, kepiting sulit untuk keluar, karena tidak ada bagian yang dapat digunakan sebagai tempat berpegangan.

Tabel 1. Sebaran hasil tangkapan rajungan (ekor).

\begin{tabular}{|c|c|c|c|c|c|c|c|c|c|c|}
\hline \multirow{3}{*}{ Trip } & \multicolumn{8}{|c|}{ Konstruksi Bubu } & \multirow{3}{*}{$\mathrm{D}(\mathrm{X}-\mathrm{Y})$} & \multirow{3}{*}{ D2 } \\
\hline & \multicolumn{4}{|c|}{ Kerucut } & \multicolumn{4}{|c|}{ Empat Persegi } & & \\
\hline & 1 & 2 & 3 & Total $(x)$ & 1 & 2 & 3 & $\operatorname{Total}(y)$ & & \\
\hline 1 & 2 & 2 & 3 & 7 & 1 & 1 & 1 & 3 & 4 & 16 \\
\hline 2 & 3 & 2 & 2 & 7 & 1 & 1 & 2 & 4 & 3 & 9 \\
\hline 3 & 3 & 3 & 2 & 8 & 2 & 1 & 2 & 5 & 3 & 9 \\
\hline 4 & 2 & 1 & 2 & 5 & 1 & 1 & 1 & 3 & 2 & 4 \\
\hline 5 & 2 & 2 & 3 & 7 & 1 & 2 & - & 3 & 4 & 16 \\
\hline 6 & 3 & 2 & 2 & 7 & 2 & 1 & 1 & 4 & 3 & 9 \\
\hline 7 & 2 & 2 & 2 & 6 & 1 & 1 & 1 & 3 & 3 & 9 \\
\hline 8 & 4 & 3 & 2 & 9 & 2 & 1 & 2 & 5 & 4 & 16 \\
\hline Jumlah & 21 & 17 & 18 & 56 & 11 & 9 & 10 & 30 & & \\
\hline Rataan & & & & 7 & & & & 3.75 & & \\
\hline
\end{tabular}

Rajungan dapat hidup pada berbagai habitat seperti pantai berpasir, pasir berlumpur dan juga laut terbuka.; dalam keadaan biasa, rajungan diam di dasar perairan sampai kedalaman $65 \mathrm{~m}$, tetapi sesekali dapat juga terlihat berada dekat permukaan. Rajungan dapat dibedakan dengan adanya beberapa tanda-tanda khusus, diantaranya adalah pinggiran depan di belakang mata, rajungan mempunyai 5 pasang kaki, yang terdiri atas 1 pasang kaki (capit) berfungsi sebagai pemegang dan memasukkan makanan kedalam mulutnya, 3 pasang kaki sebagai kaki jalan dan sepasang kaki terakhir mengalami modifikasi menjadi alat renang yang ujungnya menjadi pipih dan membundar seperti dayung (Nontji, 2005). Oleh sebab itu, rajungan dimasukan kedalam golongan kepiting berenang (swimming crab).

Ukuran rajungan antara yang jantan dan betina berbeda pada umur yang sama; jantan lebih besar dan berwarna lebih cerah serta berpigmen biru terang; sedangkan betina berwarna sedikit lebih coklat (Mirzads 2009). Rajungan jantan mempunyai ukuran tubuh lebih besar dan capitnya lebih panjang daripada betina. Perbedaan lainnya adalah warna dasar, rajungan jantan berwarna kebiru-biruan dengan bercak-bercak putih terang, sedangkan betina berwarna dasar kehijau-hijauan dengan bercak-bercak putih agak suram. Perbedaan warna ini jelas pada individu yang agak besar walaupun belum dewasa (Moosa, 1980 dalam Fatmawati 2009).
Ukuran rajungan yang ada di alam bervariasi tergantung wilayah dan musim. Berdasarkan lebar karapasnya, tingkat perkembangan rajungan dapat dibagi menjadi tiga kelompok yaitu juwana dengan lebar karapas 20-80 mm, menjelang dewasa dengan lebar 70-150 mm, dan dewasa dengan lebar karapas 150-200 mm (Mossa 1980 dalam Fatmawati 2009). Secara umum morfologi rajungan berbeda dengan kepiting bakau, di mana rajungan (Portunus pelagicus) memiliki bentuk tubuh yang lebih ramping dengan capit yang lebih panjang dan memiliki berbagai warna yang menarik pada karapasnya. Duri akhir pada kedua sisi karapas relatif lebih panjang dan lebih runcing (Anonim, 2007)

Diduga bahwa lobster (Panulirus spp), kepiting bakau (Scylla spp.) dan rajungan (Portunus spp.), telah mengalami penurunan populasi di berbagai wilayah. Dalam rangka menjaga keberadaan dan ketersediaan stok ketiga spesies tersebut, Menteri Kelautan dan Perikanan telah menetapkan peraturan Menteri Kelautan dan Perikanan nomor 1/PERMEN-KP/2015 tentang penangkapan lobster (Panulirus spp.) kepiting (Scylla spp.) dan rajungan (Potunus spp.) dapat dilakukan dengan ukuran:

(1). Lobster (Panulirus spp.), ukuran lebar karapas $>8 \mathrm{~cm}$ (berat $>300$ gram);

(2). Kepiting (Scylla spp.), ukuran lebar karapas $>15 \mathrm{~cm}$ (berat $>350$ gram);

(3). Rajungan (Portunus pelagicus), ukuran lebar karapas $>10 \mathrm{~cm}$ (berat $>55$ gram) 
Berdasarkan ukuran lebar karapaks rajungan yang tertangkap selama penelitian, maka sebanyak $56.98 \%$ belum layak tangkap dan $43.02 \%$ sudah layak tangkap menurut Permen KP RI No. 1/PERMEN-KP/2015. Karena rajungan yang tertangkap masih dalam keadaan hidup, maka sebanyak $56.98 \%$ yang belum layak tangkap dapat dikembalikan dengan aman ke laut untuk menjaga keberadaan dan ketersediaan stoknya di alam.

\section{KESIMPULAN DAN SARAN}

\section{Kesimpulan}

Konstruksi bubu bentuk kerucut terpancung menghasilkan tangkapan rajungan yang lebih banyak dibandingkan bubu konstruksi bentuk empat persegi.

\section{Saran}

(1) Penangkapan rajungan dengan bubu sebaiknya menggunakan konstruksi bentuk kerucut terpancung.

(2) Perlu kajian lebih lanjut konstruksi bubu bentuk kerucut terpancung dengan material lokal yang mudah diperoleh sehingga lebih efisien secara ekonomis.

\section{DAFTAR PUSTAKA}

Anonim. 2007. Pengamatan Aspek Biologi Rajungan dalam Menunjang Teknik Perbenihannya. Warta Penelitian Perikanan Indonesia, Volume 10, No.1.

Fatmawati. 2009. Kelimpahan Relatif dan Struktur Ukuran Rajungan Di Daerah Mangrove Kecamatan Tekolabbua Kabupaten Pangkep. Skripsi jurusan Perikanan Fakultas Ilmu Kelautan dan Perikanan Universitas Hasanuddin, Makassar.

Mirzads. 2009. Pengemasan Daging Rajungan Pasteurisasi dalam Kaleng. http://mirzads.wordpress.com/2009/02/12/ pengemasan-dagingrajungan-pasteurisasi-dalam-kaleng/. (Akses 11 Juni 2010).

Munro JL. 1974. The mode of operation of Antillen fish trap and relationships between ingress, escapement, catch and soak. Cons. Int. Explor. Mer. 35(3): 337-350.

Nasir M. 1999. Metode penelitian (Cetakan keempat). Ghalia Indonesia.

Nontji, A, 2005. Laut Nusantara. Cetakan Keempat. Djambatan. Jakarta.

Reppie E. 1989. A mathematical study on catching mechanisms of pot fishery. Master Thesis. Laboratory of Fisheries Resources Management System. Department of Marine Science and Technology. Tokyo University of Fisheries.

Reppie E. 2010. Pengaruh Minyak Cumi Pada Umpan Bubu Dasar Terhadap Hasil Tangkapan Ikan-Ikan Karang. Jurnal Perikanan dan Kelautan Tropis. Vol VI, No. 3. Desember 2010. ISSN 1411-9234

Zarochman, 1996. Klasifikasi Alat Penangkapan Ikan yang di sesuaikan untuk Perairan Indonesia. Edisi 2. Teknologi Penangkapan Ikan, Balai Pengembangan Penangkapan Ikan. Semarang. 